\title{
Personality Traits Affecting Opinion Leadership Propensity in Social Media: An Empirical Examination in Saudi Arabia
}

\author{
Suad Dukhaykh
}

check for

updates

Citation: Dukhaykh, S. Personality Traits Affecting Opinion Leadership Propensity in Social Media: An Empirical Examination in Saudi Arabia. Information 2021, 12, 323. https://doi.org/10.3390/info12080323

Academic Editor: Umair Akram

Received: 13 July 2021

Accepted: 7 August 2021

Published: 11 August 2021

Publisher's Note: MDPI stays neutral with regard to jurisdictional claims in published maps and institutional affiliations.

Copyright: (C) 2021 by the author. Licensee MDPI, Basel, Switzerland. This article is an open access article distributed under the terms and conditions of the Creative Commons Attribution (CC BY) license (https:/ / creativecommons.org/licenses/by/ $4.0 /)$.
Management Department, College of Business, King Saud University, Riyadh 11451, Saudi Arabia; sdukhaykh@KSU.EDU.SA

\begin{abstract}
Few studies have examined the personality traits that may predict opinion leadership behavior in social media. This study aims to examine the personality traits of individuals who use social media platforms and engage in social networking in Saudi Arabia. This study investigates the extent to which innovativeness, competence in interpersonal relationships, and extraversion affect the opinion leadership propensity in social media. The data were collected via an online structured questionnaire which was completed by a sample of 321 social media users. The results of this study show that people with a high level of innovativeness and interpersonal relationship competency are more likely to be opinion leaders on social media. However, the personality trait of extraversion does not affect the propensity to be an opinion leader. The results indicate that the effect of innovativeness on opinion leadership propensity is lower for Generation Y than Generation X.
\end{abstract}

Keywords: opinion leadership; social media; innovativeness; extraversion; interpersonal relationship competency; Saudi Arabia

\section{Introduction}

Recently, the necessity of social media has rapidly increased across the globe. Stone and Woodcook [1] argue that the marketing industry has increasingly become interactive, leaving companies in need of an immense understanding of their customers and their interaction with each other. In Saudi Arabia, social media has played a decisive role in the increasingly transforming the Saudi community. According to Alkhathlan [2], the Saudi people's interest in social media has developed and consequentially impacts their daily lives. Over the past few years, the Saudi Arabian economy has experienced tremendous growth. The Vision 2030 and National Transformation Program (NTP) have envisaged several plans to enable economic diversification and to develop the e-commerce sector that will enhance the economic development plans. In Saudi Arabia, buying through social media applications is widespread; business-to-consumer (B2C) e-commerce spending exceeded SAR 29.7 billion in 2016. Twitter, Instagram, and Facebook are the most used social media applications for online purchasing [3].

Online shopping using social media is more convenient as consumers find it easier to review opinions and recommendations from other consumers before deciding to purchase a product or service $[4,5]$. The increasing development of social media platforms has changed how information is collected and provided to consumers through online communication channels that enable discussion and sharing of information on products and services offered by electronic word-of-mouth (eWOM). Many studies demonstrate that when making purchase decisions, the key source used for repurchase information is electronic wordof-mouth $[4,5]$. The recommendations and opinions shared on social media networking influence purchase decisions and customer attitudes. Thus, by identifying the personality traits of opinion leaders, marketers significantly get benefits when they want to market and distribute their products. Hence, it is essential to understand the individuals who are responsible for disseminating electronic word-of-mouth (eWOM) [6]. Unfortunately, many 
organizations have been passive in identifying the opinion leaders, due to their inadequate understanding of the personality traits of these individuals $[7,8]$.

The literature that examines the personality traits of opinion leaders is still limited. Previous research that has used the Big Five personality traits are among the most frequently used; however, findings indicate that they explain only a limited percentage of the variance in an individual's behavior $[9,10]$. The Big Five personality traits are too general and broad to predict opinion leadership behavior. The personality traits of innovativeness, extraversion, and interpersonal relationship competency are more narrow, which may be better in terms of predicting opinion leadership propensity in social media. Thus, this study condenses these diverse personality traits into innovativeness, extraversion, and competence in interpersonal relationships.

This study aims to examine the personality traits of innovativeness, extraversion, and competence in interpersonal relationships on opinion leadership propensity in Saudi Arabia. The model is tested across two generational groups. Generation X (age 35 to 60) and Generation $Y$ (age 18 to 35), taking into consideration the difference in generational characteristics that may influence an individual's behavior.

The current body of literature concerning opinion leadership, social media platforms, and product adaptation has focused on findings from the United States of America. The increasing globalization of market activities results in the need to address if the existing findings comply with consumer behaviors outside the United States of America [11]. Consumers' motives to utilize social media platforms vary depending on their country of residence. Collectivist societies, such as Saudi Arabia, demonstrate outstanding engagement levels in social media networking in extended personal networks $[12,13]$. Thus, the country-level dynamics are crucial in identifying opinion leaders to increase the adoption of new products. Various scholars have identified and addressed individual trait impacts on employee behavior, such as the relationship between personality traits and organizational behavior [14,15] and individual characteristics with career outcomes [16]. Previous research that focused on the organizational context motivates this study to investigate the extent to which innovativeness, competence in interpersonal relationships, and extraversion affect opinion leadership propensity in social media.

\section{Literature Review and Hypotheses Development}

\subsection{Opinion Leaders and Innovation Diffusion}

Diffusion is defined as the process of communicating a new innovation through mass media by using word-of-mouth [17]. A number of researchers concurred that the emergence of different players in the market accelerates the diffusion rate specifically for newly launched products [18]. Opinion leaders are considered one of the main players that accelerate the process of diffusion [19]. According to Rogers [20], opinion leaders have a significant role in "activating diffusion networks" (p. 307).

In comparison with followers, opinion leaders have more access to social media and interpersonal networks [21]. Their main characteristics are knowledge, social influence, innovativeness, and interpersonal relationships [22,23]. Opinion leaders have a major influence on consumer decision-making; hence, they affect the rate of diffusion of a new product or service $[21,23,24]$.

The current body of literature has emphasized that identifying opinion leaders is crucial because they distribute information and recommendations through social media platforms about consumption choices [7,25]. Rogers [26] defined opinion leadership as the degree to which a person can positively influence others' opinions with relative frequency. Flynn et al. [6] defined opinion leaders from a marketing perspective as people whose consumers frequently rely upon as sources of information; opinion leaders exert an influence on the purchase decisions of other consumers.

There are many ways in which opinion leaders can influence the opinions or behaviors of others. Chau and Hui [27] identified three ways in which opinion leaders exert their influence on the decisions of others. First, they act as role models who motivate imitation; 
second, they spread information via word of mouth; third, they give advice and verbal direction for purchase and use.

With the advancement of communication technologies, many people now prefer to search for information using social media platforms [28]. Hence, opinion leaders are considered as influencers of consumption choices, diffusion rate, and a channel of information distribution. Researchers find that advertising and mass media are less likely to be viewed as credible or reliable sources of information than interpersonal communication [6]. However, some people with prior experience do not share their opinions with others. Thus, it is critical to identify the personality traits of these individuals who are known as opinion leaders.

\subsection{Innovativeness}

Previous research classified innovativeness personality traits into five adopter classifications: innovators, early adopters, early and late majority, and laggards [20,29]. Innovativeness is defined as "the degree to which an individual is relatively earlier in adopting an innovation than other members of his system" [30] (p. 27). High-innovativeness consumers tend to be the early consumers to try new products [31,32]. Many scholars have focused on identifying the personality traits of early adopters who are known as influential consumers. Some diffusion scholars indicated that innovativeness and opinion leadership variables are predictors of diffusion rates [22]. Additionally, previous studies have found a positive and significant relationship between innovativeness as a personality trait and opinion leadership [6,29]. Goldsmith, Flynn, and Goldsmith [33] found that opinion leadership is significantly influenced by the personality trait of innovativeness. According to Ruvio and Shoham [25], opinion leaders need to be users of new products/brands; the innovative individuals' tendency to be early in adopting new products would influence their behavior to be opinion leaders. Therefore, this study formally hypothesizes:

Hypothesis 1. Innovativeness has a positive effect on opinion leadership propensity in social media.

\subsection{Extraversion}

Extraversion is defined as the degree to which an individual is extroverted, outgoing, conversationally emphatic, and energetic [34]. Another study defined extraversion as personality traits of being dominant, confident, talkative, dynamic, and passionate [35]. Extraverts prefer to be around many people [36]. Extraversion is associated with the extent to which an individual is emphatic and active [37].

Previous studies found that opinion leaders are talkative [38], generally have a stronger social orientation [39], and they are active [40]. Extraverts welcome social interaction and are attentive to others [41-43]. Thus, extraverts are more likely to be opinion leaders [44]. Furthermore, previous literature on network opinion leadership has indicated that the status that social media opinion leaders acquire is a result of their high connections in their network [45-47]. Therefore, this study formally hypothesizes that:

Hypothesis 2. Extraversion has a positive effect on opinion leadership propensity in social media.

\subsection{Interpersonal Relationship Competency}

According to Spitzberg and Cupach [48], interpersonal relationship competency is defined as a person's ability to interact and engage with others. Opinion leadership is associated with a high degree of social engagement with others through communication and participation in social activities and affiliations with organizations [49]. Previous research has indicated that individuals with high interpersonal relationship competency are more likely to disseminate information to others [7,50,51]. Lee and Ashton [52] found that competence in interpersonal relationships is associated with a high degree of social media usage. However, Ebeling-Witte et al. [53] and Ryan and Xenos [54] indicated that socially lonely individuals tend to spend more time on social media because they feel 
insecure in face-to-face social interactions. Moreover, Sheldon [55] found that shyness is positively linked to high usage of social media platforms. Taking into consideration the mixed findings in previous studies, this study formally hypothesizes that:

Hypothesis 3. Interpersonal relationship competency has a positive effect on the propensity of opinion leadership in social media.

\section{Methodology}

\subsection{Sample and Data Collection}

The questionnaire was translated into Arabic by a Saudi Arabian native using forward translation. Another two bilingual researchers were invited to conduct back translation without having access to the original language version to eliminate any errors in meaning [56]. A pilot study was conducted with 51 respondents to check the survey accuracy. The respondents understood all the questions in the questionnaire; this sample was excluded from the actual survey respondents in this study. The Google Form survey was sent to a marketing company specializing in online data collection to collect the data from panelists of consumers. The participants in this study were consumers aged 18 years and older who had used and engaged in social networking (e.g., Twitter, Facebook, Instagram, online communications, etc.,) in Saudi Arabia. Within two weeks, a total of 321 responses were collected. The demographic characteristics of respondents are shown in Table 1. The genders of the respondents were $29 \%$ male and $72 \%$ female. The majority of the respondents reported an age range of $18-35$. The population was vastly educated; $48.6 \%$ of respondents had a bachelor's degree, and $27.6 \%$ had a master's degree. Approximately $29 \%$ of the respondents reported that they frequently used social media three to five hours per day; $23.1 \%$ used it five to seven hours per day, and $20.6 \%$ noted that they used social media from one to three hours per day.

Table 1. Demographics of research sample $(\mathrm{N}=321)$.

\begin{tabular}{cccccc}
\hline & Female & Male & & & \\
\hline \multirow{2}{*}{ Gender } & $71.00 \%$ & $29.00 \%$ & & & \\
\cline { 2 - 6 } Age & $18-25$ & $25-35$ & $35-45$ & $45-55$ & $>55$ \\
& $23.40 \%$ & $40.80 \%$ & $24.00 \%$ & $8.70 \%$ & $3.10 \%$ \\
\cline { 2 - 6 } Education Level & High School & Diploma & Bachelor & Master & Ph.D. \\
& $13.10 \%$ & $4.70 \%$ & $48.60 \%$ & $27.70 \%$ & $5.90 \%$ \\
\cline { 2 - 6 } Frequency & $1-3 \mathrm{H}$ & $3-5 \mathrm{H}$ & $5-7 \mathrm{H}$ & $7-9 \mathrm{H}$ & $>9 \mathrm{H}$ \\
\cline { 2 - 6 } & $20.60 \%$ & $29.00 \%$ & $23.10 \%$ & $14.60 \%$ & $12.80 \%$ \\
\hline
\end{tabular}

\subsection{Measures}

Data were collected using a structured online survey that contained questions designed to measure the following variables: dispositional innovativeness, extraversion, interpersonal relationship competency, and opinion leadership propensity. All of the scales used in this study were modified to reflect the context. All of the independent variables were measured on a 5- point Likert-type scale ranging from "strongly disagree" (1) to "strongly agree" (5). The measure of dispositional innovativeness was adapted from Steenkamp and Gielens [57]; extraversion was adapted from John et al. [58]; interpersonal relationship competency was adapted from Davis [59], and opinion leadership propensity (OLP) was adopted from the opinion leadership scale of Childers [60]. Please check Appendix A.

\section{Measurement Model Results}

An exploratory factor analysis (EFA) and confirmatory factor analysis (CFA) were performed to verify the unidimensionality, validity, and reliability of the model constructs. 
SPSS v22 was used to conduct the EFA on the measures using maximum likelihood factoring and Promax oblique rotation method. AMOS v28 was used to perform CFA, common method bias (CMB), measurement invariance, and structural equation modeling (SEM).

\subsection{Exploratory Factor Analysis}

All items were submitted to exploratory factor analysis. Maximum likelihood with Promax rotation was used to examine the factor structure, maximize differences between factors, and provide model fit estimates [61]. The factor loadings and cross-loadings of the items were examined. Items were retained if (a) they had high loadings on their primary factor (i.e., $1>0.40$ ) and (b) they had low cross-loadings on any other factor (i.e., cross-loadings were less than half of their primary loadings [62].

Several statistics indicated the EFA solution was acceptable. Bartlett's test of sphericity was significant $(\chi 2=982.339, \mathrm{df}=45, p<0.000)$ indicating sufficient intercorrelations. The communalities were all above 0.40 , further confirming that each item shared some common variance with other items. In addition, the values of Cronbach's alphas were greater than the recommended level of 0.70 [63].

\subsection{Confirmatory Factor Analysis}

The measurement model was established using AMOS v28.0, a covariance-based SEM technique that uses the maximum likelihood approach. In the CFA model, no unidirectional path was specified between any latent. However, a covariance model was estimated where each latent variable was correlated with every other latent variable.

The psychometric properties of the nine latent constructs were evaluated simultaneously in one confirmatory factor analysis (CFA). It is generally recommended that multiple indices be considered simultaneously when the overall model fit is evaluated. The results indicated that the model fit the data very well. No problems were detected in residuals or standard errors. As shown in Table 2, a decent model fit was obtained [64].

Table 2. Model fit.

\begin{tabular}{ccccccccccc}
\hline Chi-Square & $\begin{array}{c}\text { Degrees of } \\
\text { Freedom }\end{array}$ & CMIN/DF & $p$ Value & CFI & TLI & RMSEA & RMR & AGFI & GFI & $\begin{array}{c}p \\
\text { CLOSE }\end{array}$ \\
\hline 52.393 & 29 & 1.807 & 0.005 & 0.975 & 0.962 & 0.050 & 0.032 & 0.939 & 0.968 & 0.465 \\
\hline
\end{tabular}

\subsection{Convergent and Discriminant Validity}

For assessing convergent validity, three standards recommended by Bagozzi and Yi [65] were used to assess the measuring model: (1) all indicator CFA factor loadings should exceed 0.5 [66]; (2) CR should be above 0.7 ; and (3) the average variance extracted (AVE) of every construct should exceed 0.5 [67]. As shown in Table 3, the convergent validity for the proposed constructs of this study was adequate. For discriminant validity, Fornell and Larcker [67] recommend that the AVE of the construct should exceed the construct's correlation coefficients. Table 3 shows the matrix of correlations among the constructs in this research. The correlation coefficients between any two constructs are smaller than the square root of the average variance extracted for the constructs. Constructs in the measurement model of this research were different from one another, indicating that all constructs in this research had adequately discriminant validity. Furthermore, to examine the discriminate validity of the measurement model, the correlations between latent constructs were examined. High-value correlations that exceed 0.9 or correlations exceeding 0.85 should be noted as an indication of intercorrelated constructs $[66,68]$. Therefore, the measurement model in this research shows satisfactory reliability, convergent and discriminant validity [64]. 
Table 3. Reliability, convergent validity, and discriminant validity.

\begin{tabular}{cccccccccc}
\hline & CR & AVE & MSV & MaxR(H) & $\mathbf{1}$ & $\mathbf{2}$ & $\mathbf{3}$ & $\mathbf{4}$ \\
\hline 1. Interpersonal relationship & 0.801 & 0.581 & 0.226 & 0.847 & 0.762 & & & \\
2. Extraversion & 0.827 & 0.706 & 0.116 & 0.833 & 0.341 & 0.840 & & \\
3. Innovativeness & 0.730 & 0.576 & 0.023 & 0.750 & 0.082 & 0.150 & 0.690 & \\
\cline { 2 - 8 } 4. Opinion leadership propensity & 0.711 & 0.556 & 0.226 & 0.748 & 0.475 & 0.295 & 0.151 & 0.745 \\
\hline
\end{tabular}

CR—composite reliability. AVE—average variance extracted. MSV—maximum shared variance.

\subsection{Measurement Invariance}

Before performing a multigroup analysis in the structural model, scalar invariance was conducted to examine whether groups use the response scale in a similar way [66]. The equality of intercepts across the groups (Generation X and Generation Y) was checked by constraining the intercepts of all the items for the two generational groups to be equal. The chi-square difference between the full scalar invariance model and nonrestricted model was significant: (CMIN $=32.11, \mathrm{DF}=10, p<0.000)$. Thus, partial scalar invariance was performed to compare the intercepts of the unconstrained model with the equal intercepts model to see which items had a significant difference at the intercept level. Two items at the intercept level differed significantly. After relaxing these items to be freely estimated at the intercept level, the chi-square difference between the partial scalar invariance model and the nonrestricted model became insignificant $(\mathrm{CMIN}=15.144, \mathrm{DF}=8, p>0.05)$.

\subsection{Common Method Bias}

Research is particularly susceptible to method bias when a single data collection is used to collect data [69]. A common latent factor (CLF) was added, and three nested models were created. The first is the unconstrained model; the second is equal loadings; and the third one is equal to zero loadings model. The significant $p$-values shown in the model comparison results suggest that the nested models fitted the data worse; thus, the unrestricted model fitted the data better. Therefore, these findings suggest common method bias is significant. The unconstrained model had the better fitting model of the three. That is, the model that accounted for a variance from a common factor fit better than the model that assumed there was no indicator variance from the CLF factor (i.e., when the indicator loadings were set to 0 ) and the model that assumed the CLF factor had equal loadings, which is not reliable [70]. Thus, the CLF was retained when the composites from factor scores were imputed to perform the structural model.

\section{Structural Model Results}

\subsection{Descriptive Statistics}

The means, standard deviations, reliabilities, and correlation between the study variables are shown in Table 4. All variables have acceptable reliabilities [66].

Table 4. Means, standard deviations, Cronbach's alphas, and intercorrelations among study variables.

\begin{tabular}{ccccccc}
\hline & Mean & SD & $\mathbf{1}$ & $\mathbf{2}$ & $\mathbf{3}$ & $\mathbf{4}$ \\
\hline Innovativeness & 1.8137 & 0.50174 & $\mathbf{0 . 7 2 0}$ & & & \\
Extraversion & 0.9656 & 0.39610 & $0.440^{* *}$ & $\mathbf{0 . 8 2 7}$ & & \\
Interpersonal & 2.2038 & 0.46783 & $0.176^{* *}$ & $-0.246^{* *}$ & $\mathbf{0 . 7 8 7}$ & \\
OLP & 1.5936 & 0.47069 & $0.212^{* *}$ & 0.020 & $0.377^{* *}$ & $\mathbf{0 . 7 1 0}$ \\
\hline ** Correlation is significant at the 0.01 level (2-tailed).
\end{tabular}

** Correlation is significant at the 0.01 level (2-tailed).

\subsection{Direct Effects within the Structural Equation Model}

Figure 1 shows that Hypotheses 1 and 3 are supported as there were direct significant effects within the SEM. Innovativeness is positively related to opinion leadership propensity ( $\beta=0.148, p<0.05)$. Competency in interpersonal relationships is positively related to 
opinion leadership propensity $(\beta=0.337, p<0.001)$. However, extraversion does not relate positively to opinion leadership propensity $(\beta=0.002, p>0.05)$.

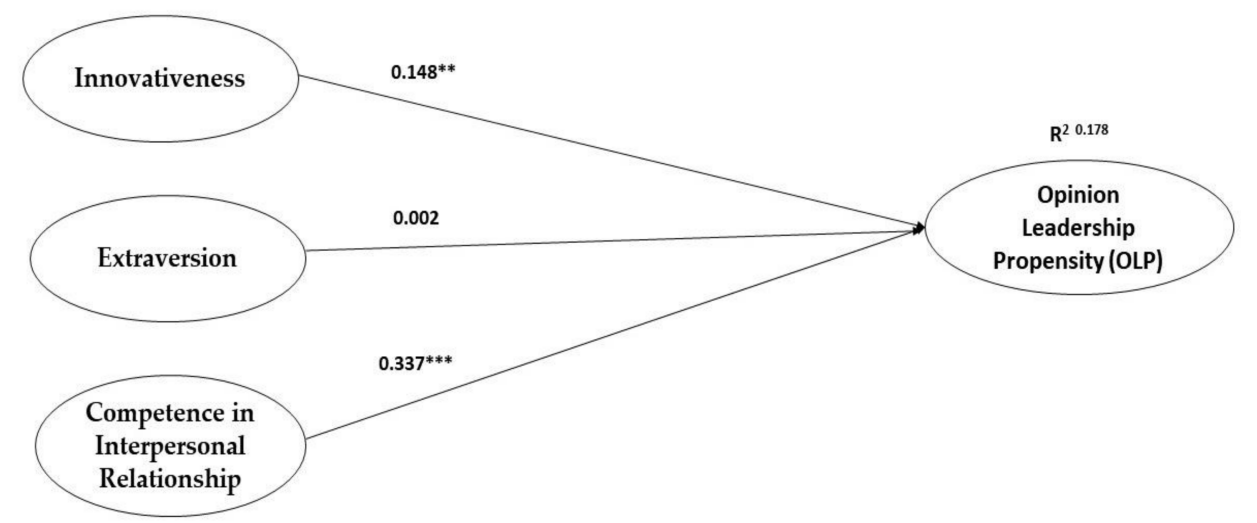

Figure 1. Hypothesized model results. Note: ${ }^{* *} p<0.01,{ }^{* * *} p<0.001$.

\subsection{Multiple-Group Analyses}

For the multigroup structural modeling, two models were created: the unconstrained model and the equal constrained model [71]. The chi-square difference across the two generational groups was insignificant, rejecting group differences $(\mathrm{CMIN}=15.265, \mathrm{DF}=8$, $p=0.054$ ). A path-by-path constraint where each path sat to be equal was performed to detect whether there was a difference at the path level. It was found that there was a difference across the two generational groups in one path. The $\Delta \times 2$ of the relationship between innovativeness and opinion leadership propensity was statistically significant (CMIN $=4.549$, $\mathrm{DF}=1, p=0.033$ ), supporting group differences. The coefficient value from innovativeness to opinion leadership propensity was stronger for generation $X\left(\beta=0.325^{* * *}\right)$ than generation $Y\left(\beta=0.123^{* *}\right)$. However, there was no significant difference in the coefficient value from extraversion to opinion leadership propensity and from the interpersonal relationship to opinion leadership propensity. The two items that were relaxed to be equal in the measurement model to achieve the partial scalar invariance were under the innovativeness construct, supporting the findings of the group differences in the structural model.

\section{Discussion}

The objective of the study was to investigate the personality traits that drive customers to become opinion leaders. This research makes a critical theoretical contribution to the existing literature on opinion leadership. This study documents that innovativeness has a significant effect on opinion leadership propensity in social media. People with a high level of innovativeness have a greater tendency to share information on social media. This finding is in line with findings in the previous literature by Goldsmith and Hofacker [29] and Flynn et al. [6]. Ruvio and Shoham [25] indicated that for individuals to be opinion leaders, they need to be users of new products. Previous research has documented a positive relationship between innovativeness and opinion leadership. Goldsmith and Hofacker [29] found a positive relationship between consumer innovativeness and opinion leadership. Additionally, Flynn et al. [6] reported a significant positive relationship in their study of fashion-related products. Innovative individuals are willing to take the risk of trying new products/brands and to cope with a high level of uncertainty. As a result, they share their experience and knowledge through (EWOM) that could influence others' purchasing behaviors [72].

With respect to interpersonal relationship competency, the result shows that the trait of competence in interpersonal relationships also increases the propensity to be an opinion leader in social media and is critical to being an opinion leader. This finding is in line with previous studies that have indicated that those with high competence in interpersonal relationships are more likely to share referral information with others [51,73]. Orchard and 
Fullwood [74] suggest that personality traits translate to social media usage at a high level, and individuals engage in social media activities to satisfy their needs. Another study by Gangadharbatla [50] indicated that individuals with a high belongingness desire were more likely to use social media platforms.

Diverging from existing work on the relationship between extraversion and opinion leadership behavior, this study finds that extraversion does not influence the propensity to be an opinion leader in social media. Correa et al. [75] found that extraversion is positively related to social media usage. Akdevelioglu and Kara [76] found that extraversion affects social media opinion leadership. However, previous studies indicated that shy individuals are more likely to use social media platforms $[10,55]$. Thus, introversion personality traits may be a better predictor of the propensity to be an opinion leader in the context that this research is investigating.

\section{Practical Implications}

This research has several practical implications for practitioners and marketers. First, practitioners need to identify influential people in social media. This study provides significant information that would help companies accelerate the diffusion of new products. Second, and more importantly, by examining the effect of innovativeness, extraversion, and interpersonal relationship competency on opinion leadership propensity in Saudi Arabia, this research has implications for effectively identifying opinion leader dynamics in another context [77]. Examining the personality traits of consumers who engage in social media networking in different contexts is important for marketers, so they can establish segmentation based on cultural characteristics, such as uncertainty avoidance and individualism/collectivism [13,76]. This study also highlights the importance of interpersonal relationship competency and innovativeness in the identification of opinion leaders in Saudi Arabia. For example, for Saudi Arabia (high in collectivism), interpersonal relationship competency is a better indicator for opinion leadership, whereas innovativeness (high in uncertainty avoidance) is a lower indicator for opinion leadership. With the advancement in marketing analytics tools, it is easier for companies to analyze social media data to identify and target opinion leaders who are high in both innovativeness and interpersonal relationship competency.

Further, it is crucial to target the opinion leaders in order to accelerate the diffusion rate because they use word-of-mouth to influence the behavior of others [22]. Thus, creating communication channels to reach opinion leaders helps to accelerate the diffusion rate [23].

\section{Limitations and Future Research}

The current study has some limitations. First, common method bias when self-report is used to collect data is a limitation for this study. To provide more valid results, future research should integrate different data collection methods, such as self-ratings and peer ratings in order to correct for the bias of using a single data collection method [78]. Second, an important extension of this study would be to examine the influence of other demographic factors, such as educational level, income, and privacy. Third, the moderating effect of age was used as a categorical variable; the literature indicates that there are many psychological and behavioral differences between the two generational groups [79]. A future study to examine age as a continuous moderating variable is recommended. Fourth, it would be interesting to examine the moderating effect of gender.

Funding: This research received no external funding.

Institutional Review Board Statement: Not applicable.

Informed Consent Statement: Not applicable.

Data Availability Statement: Data sharing is not applicable. The data are not publicly available due to participants' privacy. 
Acknowledgments: This research is supported by the deanship of scientific research at King Saud University.

Conflicts of Interest: The author declares no conflict of interest.

\section{Appendix A. Measures}

\begin{tabular}{|c|c|c|}
\hline Constructs & Items & Rating Scale \\
\hline $\begin{array}{l}\text { Dispositional } \\
\text { innovativeness }\end{array}$ & $\begin{array}{l}\text { 1. When I see a product on the shelf, I'm reluctant to give it a try }\left(^{*}\right) \\
\text { 2. In general, I am among the first to buy new products when they } \\
\text { appear on the market } \\
\text { 3. If I like a brand, I rarely switch from it just to try something new }\left(^{*}\right) \\
\text { 4. I am very cautious in trying new and different products }\left(^{*}\right) \\
\text { 5. I am usually among the first to try new brands } \\
\text { 6. I rarely buy brands about which I am uncertain how they } \\
\text { will perform } \\
\text { 7. I enjoy taking chances in buying new products } \\
\text { 8. I do not like to buy a new product before other people }\left(^{*}\right)\end{array}$ & $\begin{array}{c}\text { Strongly disagree (1)-strongly } \\
\text { agree (5) }\end{array}$ \\
\hline Extraversion & $\begin{array}{l}\text { 1. I am someone who is talkative. } \\
\text { 2. I am someone who is reserved }\left(^{*}\right) \\
\text { 3. I am someone who is full of energy } \\
\text { 4. I am someone who generates a lot of enthusiasm } \\
\text { 5. I am someone who tends to be quiet }\left(^{*}\right) \\
\text { 6. I am someone who has an assertive personality } \\
\text { 7. I am someone who is sometimes shy, inhibited }\left(^{*}\right) \\
\text { 8. I am someone who is outgoing }\end{array}$ & $\begin{array}{c}\text { Strongly disagree (1)-strongly } \\
\text { agree (5) }\end{array}$ \\
\hline $\begin{array}{l}\text { Interpersonal } \\
\text { relationship } \\
\text { competency }\end{array}$ & $\begin{array}{l}\text { 1. I am helpful to others. } \\
\text { 2. I am aware of the feelings of others. } \\
\text { 3. I am understanding of others. } \\
\text { 4. I have warm relationships with others. }\end{array}$ & $\begin{array}{c}\text { Strongly disagree (1)-strongly } \\
\text { agree (5) }\end{array}$ \\
\hline $\begin{array}{l}\text { Opinion leadership } \\
\text { propensity }\end{array}$ & $\begin{array}{l}\text { 1. When I talk to my friends in social media, I give: } \\
\text { 2. When social networking with my friends, the extent to which they } \\
\text { rely on me as a source of advice is: } \\
\text { 3. Overall, in all of my discussions on social media with friends, I am: } \\
\text { 4. On certain issues among people participating in social network } \\
\text { with me, I am: }\end{array}$ & $\begin{array}{l}\text { Very little information (1)-a } \\
\text { great deal of information (5) } \\
\text { Very low (1)-very high (5) } \\
\text { Not at all used as a source of } \\
\text { advice (1)-very often used as a } \\
\quad \text { source of advice (5) } \\
\text { Not at all asked to provide my } \\
\text { opinion (1)-Very often asked to } \\
\text { provide my opinion (5) }\end{array}$ \\
\hline
\end{tabular}

Note: $(*)$ Reverse coded items.

\section{References}

1. Stone, M.D.; Woodcock, N.D. Interactive, direct and digital marketing. J. Res. Interact. Mark. 2014, 8, 4-17. [CrossRef]

2. Alkhathlan, S. Students' Engagement in Independent Learning and Personal Development: Issues, Attitudes and Difficulties from the Female Learners' Lived Experiences of Using Social Media in the Context of Saudi Higher Education. Ph.D. Dissertation, University of Exeter, Exeter, UK, 2019.

3. Communications and Information Technology Commission. ICT Report: E-Commerce in Saudi Arabia. Available online: https://www.citc.gov.sa/en/reportsandstudies/Reports/Documents/CITC_ECOMMERCE_2017_ENGLISH.PDF (accessed on 1 August 2021).

4. Couture, A.; Arcand, M.; Sénécal, S.; Ouellet, J.-F. The influence of tourism innovativeness on online consumer behavior. J. Travel Res. 2015, 54, 66-79. [CrossRef]

5. Litvin, S.W.; Goldsmith, R.E.; Pan, B. Electronic word-of-mouth in hospitality and tourism management. Tour. Manag. 2008, 29, 458-468. [CrossRef]

6. Flynn, L.R.; Goldsmith, R.E.; Eastman, J.K. Opinion leaders and opinion seekers: Two new measurement scales. J. Acad. Mark. Sci. 1996, 24, 137. [CrossRef]

7. Song, S.Y.; Cho, E.; Kim, Y.-K. Personality factors and flow affecting opinion leadership in social media. Personal. Individ. Differ. 2017, 114, 16-23. [CrossRef] 
8. Gardiner, S.; Grace, D.; King, C. The generation effect: The future of domestic tourism in Australia. J. Travel Res. 2014, 53, 705-720. [CrossRef]

9. Hughes, D.J.; Rowe, M.; Batey, M.; Lee, A. A tale of two sites: Twitter vs. Facebook and the personality predictors of social media usage. Comput. Hum. Behav. 2012, 28, 561-569. [CrossRef]

10. Orr, E.S.; Sisic, M.; Ross, C.; Simmering, M.G.; Arseneault, J.M.; Orr, R.R. The influence of shyness on the use of Facebook in an undergraduate sample. CyberPsychol. Behav. 2009, 12, 337-340. [CrossRef] [PubMed]

11. Erdem, T.; Swait, J.; Valenzuela, A. Brands as signals: A cross-country validation study. J. Mark. 2006, 70, 34-49. [CrossRef]

12. Hartzel, K.S.; Marley, K.A.; Spangler, W.E. Online social network adoption: A cross-cultural study. J. Comput. Inf. Syst. 2016, 56, 87-96. [CrossRef]

13. Hofstede, G. Culture's Consequences: Comparing Values, Behaviors, Institutions and Organizations Across Nations, 2nd ed.; Sage Publications: Thousand Oaks, CA, USA, 2001.

14. Helle, A.C.; DeShong, H.L.; Lengel, G.J.; Meyer, N.A.; Butler, J.; Mullins-Sweatt, S.N. Utilizing Five Factor Model facets to conceptualize counterproductive, unethical, and organizational citizenship workplace behaviors. Personal. Individ. Differ. 2018, 135, 113-120. [CrossRef]

15. Bourdage, J.S.; Goupal, A.; Neilson, T.; Lukacik, E.-R.; Lee, N. Personality, equity sensitivity, and discretionary workplace behavior. Personal. Individ. Differ. 2018, 120, 144-150. [CrossRef]

16. Judge, T.A.; Zapata, C.P. The person-situation debate revisited: Effect of situation strength and trait activation on the validity of the big five personality traits in predicting job performance. Acad. Manag. J. 2015, 58, 1149-1179. [CrossRef]

17. Hafeez, K.; Hooi Keoy, K.; Hanneman, R. E-business capabilities model. J. Manuf. Technol. Manag. 2006, 17, 806-828. [CrossRef]

18. Van den Bulte, C. New product diffusion acceleration: Measurement and analysis. Mark. Sci. 2000, 19, 366-380. [CrossRef]

19. Forlani, D.; Parthasarathy, M. Dynamic market definition: An international marketing perspective. Int. Mark. Rev. 2003, 20, 142-160. [CrossRef]

20. Rogers, E.M. Diffusion of Innovations, 3rd ed.; The Free Press: New York, NY, USA, 1983.

21. Rogers, E.M. Diffusion of Innovations, 5th ed.; The Free Press: New York, NY, USA, 2003.

22. Goldsmith, R.E.; De Witt, T.S. The predictive validity of an opinion leadership scale. J. Mark. Theory Pract. 2003, 11, 28-35. [CrossRef]

23. Lyons, B.; Henderson, K. Opinion leadership in a computer-mediated environment. J. Consum. Behav. 2005, 4, 319-329. [CrossRef]

24. Dearing, J.W. Applying diffusion of innovation theory to intervention development. Res. Soc. Work Pract. 2009, 19, 503-518. [CrossRef]

25. Ruvio, A.; Shoham, A. Innovativeness, exploratory behavior, market mavenship, and opinion leadership: An empirical examination in the Asian context. Psychol. Mark. 2007, 24, 703-722. [CrossRef]

26. Rogers, E.M.; Cartano, D.G. Methods of measuring opinion leadership. Public Opin. Q. 1962, 26, 435-441. [CrossRef]

27. Chau, P.Y.K.; Hui, K.L. Identifying early adopters of new IT products: A case of Windows 95. Inf. Manag. 1998, 33, 225-230. [CrossRef]

28. Bilal, M.; Jianqiu, Z.; Dukhaykh, S.; Fan, M.; Trunk, A. Understanding the effects of eWOM antecedents on online purchase intention in China. Information 2021, 12, 192. [CrossRef]

29. Goldsmith, R.E.; Hofacker, C.F. Measuring consumer innovativeness. J. Acad. Mark. Sci. 1991, 19, 209-221. [CrossRef]

30. Rogers, E.M.; Shoemaker, F.F. Communication of Innovations: A Cross-Cultural Approach; The Free Press: New York, NY, USA, 1971.

31. Assael, H. Consumer Behavior and Marketing Action; PWS-Kent: Boston, MA, USA, 1992.

32. Schiffman, L.G.; Kanuk, L.L. Consumer Behavior; Pearson Education: Upper Saddle River, NJ, USA, 2004.

33. Goldsmith, R.E.; Flynn, L.R.; Goldsmith, E.B. Innovative consumers and market mavens. J. Mark. Theory Pract. 2003, 11, 54-65. [CrossRef]

34. Barrick, M.R.; Mount, M.K. The big five personality dimensions and job performance: A meta-analysis. Pers. Psychol. 1991, 44, 1-26. [CrossRef]

35. Zhao, H.; Seibert, S.E. The Big Five personality dimensions and entrepreneurial status: A meta-analytical review. J. Appl. Psychol. 2006, 91, 259-271. [CrossRef]

36. LePine, J.A.; Van Dyne, L. Voice and cooperative behavior as contrasting forms of contextual performance: Evidence of differential relationships with Big Five personality characteristics and cognitive ability. J. Appl. Psychol. 2001, 86, 326-336. [CrossRef]

37. Fayombo, G. The relationship between personality traits and psychological resilience among the Caribbean adolescents. Int. J. Psychol. Stud. 2010, 12, 105-116. [CrossRef]

38. Weimann, G. The influentials: Back to the concept of opinion leaders? Public Opin. Q. 1991, 55, 267-279. [CrossRef]

39. Venkatraman, M.P. Opinion leadership, enduring involvement and characteristics of opinion leaders: A moderating or mediating relationship. Adv. Consum. Res. 1990, 17, 60-67.

40. Booth, A.; Babchuk, N. Informal medical opinion leadership among the middle aged and elderly. Public Opin. Q. 1972, 36, 87-94. [CrossRef]

41. Pagani, M.; Goldsmith, R.E.; Hofacker, C.F. Extraversion as a stimulus for user-generated content. J. Res. Interact. Mark. 2013, 7, 242-256. [CrossRef]

42. Klein, K.J.; Lim, B.-C.; Saltz, J.L.; Mayer, D.M. How do they get there? An examination of the antecedents of centrality in team networks. Acad. Manag. J. 2004, 47, 952-963. [CrossRef] 
43. Mooradian, T.A.; Matzler, K.; Szykman, L. Empathetic responses to advertising: Testing a network of antecedents and consequences. Mark. Lett. 2008, 19, 79-92. [CrossRef]

44. Venkatesh, A.; Akdevelioglu, D. Social media consumer as digital avatar. In Routledge Handbook on Consumption; Keller, M., Halkier, B., Wilska, T.-A., Truninger, M., Eds.; Routledge: New York, NY, USA, 2017; pp. 453-465.

45. Darley, W.; Lim, J.-S. Mavenism and e-maven propensity: Antecedents, mediators and transferability. J. Res. Interact. Mark. 2018, 12, 293-308. [CrossRef]

46. Iyengar, R.; Van den Bulte, C.; Valente, T.W. Opinion leadership and social contagion in new product diffusion. Mark. Sci. 2011, 30, 195-212. [CrossRef]

47. Goldsmith, R.E.; Pagani, M.; Lu, X. Social network activity and contributing to an online review site. J. Res. Interact. Mark. 2013, 7, 100-118. [CrossRef]

48. Spitzberg, B.H.; Cupach, W.R. Handbook of Interpersonal Competence Research; Springer: New York, NY, USA, 1989.

49. Summers, J.O. The identity of women's clothing fashion opinion leaders. J. Mark. Res. 1970, 7, 178-185. [CrossRef]

50. Gangadharbatla, H. Facebook me: Collective self-esteem, need to belong, and internet self-efficacy as predictors of the Igeneration's attitudes toward social networking sites. J. Interact. Advert. 2008, 8, 5-15. [CrossRef]

51. Wang, J.-L.; Jackson, L.A.; Wang, H.-Z.; Gaskin, J. Predicting Social Networking Site (SNS) use: Personality, attitudes, motivation and Internet self-efficacy. Personal. Individ. Differ. 2015, 80, 119-124. [CrossRef]

52. Lee, K.; Ashton, M.C. Psychometric properties of the HEXACO Personality Inventory. Multivar. Behav. Res. 2004, 39, 329-358 [CrossRef] [PubMed]

53. Ebeling-Witte, S.; Frank, M.L.; Lester, D. Shyness, internet use, and personality. CyberPsychol. Behav. 2007, 10, 713-716. [CrossRef]

54. Ryan, T.; Xenos, S. Who uses Facebook? An investigation into the relationship between the Big Five, shyness, narcissism, loneliness, and Facebook usage. Comput. Hum. Behav. 2011, 27, 1658-1664. [CrossRef]

55. Sheldon, P. The relationship between unwillingness-to-communicate and students' Facebook use. J. Media Psychol. 2008, 20, 67-75. [CrossRef]

56. Brislin, R.W. Back-translation for cross-cultural research. J. Cross Cult. Psychol. 1970, 1, 185-216. [CrossRef]

57. Steenkamp, J.-B.E.M.; Gielens, K. Consumer and market drivers of the trial probability of new consumer packaged goods. J. Consum. Res. 2003, 30, 368-384. [CrossRef]

58. John, O.P.; Naumann, L.P.; Soto, C.J. Paradigm shift to the integrative Big Five trait taxonomy: History, measurement, and conceptual issues. In Handbook of Personality: Theory and Research, 3rd ed.; John, O.P., Robins, R.W., Pervin, L.A., Eds.; The Guilford Press: New York, NY, USA, 2008; pp. 114-158.

59. Davis, M.H. Measuring individual differences in empathy: Evidence for a multidimensional approach. J. Personal. Soc. Psychol. 1983, 44, 113-126. [CrossRef]

60. Childers, T.L. Assessment of the psychometric properties of an opinion leadership scale. J. Mark. Res. 1986, 23, 184-188. [CrossRef]

61. Fabrigar, L.R.; Wegener, D.T.; MacCallum, R.C.; Strahan, E.J. Evaluating the use of exploratory factor analysis in psychological research. Psychol. Methods 1999, 4, 272-299. [CrossRef]

62. Hinkin, T.R. A brief tutorial on the development of measures for use in survey questionnaires. Organ. Res. Methods 1998, 1, 104-121. [CrossRef]

63. Nunnally, J.C.; Bernstein, I.H. Psychometric Theory, 3rd ed.; McGraw-Hill: New York, NY, USA, 1994.

64. Hu, L.T.; Bentler, P.M. Cutoff criteria for fit indexes in covariance structure analysis: Conventional criteria versus new alternatives. Struct. Equ. Model. A Multidiscip. J. 1999, 6, 1-55. [CrossRef]

65. Bagozzi, R.P.; Yi, Y. On the evaluation of structural equation models. J. Acad. Mark. Sci. 1988, 16, 74-94. [CrossRef]

66. Hair, J.F., Jr.; Black, W.C.; Babin, B.J.; Anderson, R.E. Multivariate Data Analysis, 7th ed.; Pearson Prentice Hall: Upper Saddle River, NJ, USA, 2010.

67. Fornell, C.; Larcker, D.F. Evaluating structural equation models with unobservable variables and measurement error. J. Mark. Res. 1981, 18, 39-50. [CrossRef]

68. Kline, R.B. Software review: Software programs for structural equation modeling: Amos, EQS, and LISREL. J. Psychoeduc. Assess. 1998, 16, 343-364. [CrossRef]

69. Podsakoff, P.M.; MacKenzie, S.B.; Lee, J.-Y.; Podsakoff, N.P. Common method biases in behavioral research: A critical review of the literature and recommended remedies. J. Appl. Psychol. 2003, 88, 879-903. [CrossRef]

70. Archimi, C.S.; Reynaud, E.; Yasin, H.M.; Bhatti, Z.A. How perceived corporate social responsibility affects employee cynicism: The mediating role of organizational trust. J. Bus. Ethics 2018, 151, 907-921. [CrossRef]

71. Koufteros, X.; Marcoulides, G.A. Product development practices and performance: A structural equation modeling-based multi-group analysis. Int. J. Prod. Econ. 2006, 103, 286-307. [CrossRef]

72. Thakur, R.; Angriawan, A.; Summey, J.H. Technological opinion leadership: The role of personal innovativeness, gadget love, and technological innovativeness. J. Bus. Res. 2016, 69, 2764-2773. [CrossRef]

73. Amichai-Hamburger, Y.; Vinitzky, G. Social network use and personality. Comput. Hum. Behav. 2010, 26, 1289-1295. [CrossRef]

74. Orchard, L.J.; Fullwood, C. Current perspectives on personality and internet use. Soc. Sci. Comput. Rev. 2010, 28, 155-169. [CrossRef]

75. Correa, T.; Hinsley, A.W.; de Zúñiga, H.G. Who interacts on the Web? The intersection of users' personality and social media use. Comput. Hum. Behav. 2010, 26, 247-253. [CrossRef] 
76. Akdevelioglu, D.; Kara, S. An international investigation of opinion leadership and social media. J. Res. Interact. Mark. 2020, 14, 71-88. [CrossRef]

77. Kim, Y.; Sohn, D.; Choi, S.M. Cultural difference in motivations for using social network sites: A comparative study of American and Korean college students. Comput. Hum. Behav. 2011, 27, 365-372. [CrossRef]

78. Nederhof, A.J. Methods of coping with social desirability bias: A review. Eur. J. Soc. Psychol. 1985, 15, 263-280. [CrossRef]

79. Huang, Y.-C.; Petrick, J.F. Generation Y's travel behaviours: A comparison with baby boomers and generation X. In Tourism and Generation Y; Pendergast, D., Moscardo, G., Benckendorff, P., Eds.; CAB International: Wallingford, UK, 2010 ; pp. 27-37. 